\title{
Using the Urban Advantage to Achieve the Greatest Good
}

\author{
Vicki L. Golich
}

Just as urban and metropolitan universities and colleges serve an important role in their communities, cities serve important roles in students’ academic and personal growth. Urban institutions provide them with the resources to grow and thrive in a fast-paced environment. With better opportunities for experiential learning, research and development, creative activity, and partnerships that create immediate and substantive impact on communities, this urban advantage was the focus of the 23rd Annual CUMU Conference "The Urban Advantage" (CUMU, 2017). The conference was held in Denver, Colorado in October 2017. Presentations explored the unique learning opportunities provided by urban universities known to improve student persistence and successful career development (AAC\&U, n.d.). Scholars and activists called for urban IHEs to consider how they might engage with their surrounding communities more effectively to solve problems, improve the local economy, and educate a professional $21^{\text {st }}$ century-relevant workforce. Finally, they underscored the imperative that metropolitan colleges and universities stay true to their public mission.

The keynote speakers for this conference-Holland, Howard, and Seligsohn—set the stage for these presentations and conversations in a plenary session titled "Voices from the Field." Their powerful rhetoric both challenged and congratulated participants. Holland noted, in particular, that IHE leaders must manage the changing landscape of higher education, while keeping grounded in the purpose of a university degree. Howard reminded us that colleges and universities should leverage and harmonize their institutional assets to support surrounding communities, as this achieves "mutual, shared, enlightened self-interest of the very best kind." Finally, Seligsohn encouraged conference attendees to avoid the false dichotomy that sees civic education as distinct from career preparation. In doing so, he reminded all that "a powerful positive relationship between engaged citizens and community members ... and economic prosperity," and that civic-minded citizens will demand positive political behavior from elected officials.

This issue includes two winners of the Ernest A. Lynton Award for the Scholarship of Engagement. The 2015 winner, DeMeulenaere, describes his personal journey that brought him to combine the teaching, research, and service obligations of a tenure-line faculty member with his passion to engage in activism to achieve social justice for all. Walker, the 2017 recipient, and co-author, East, present two case studies of institutions that engaged their surrounding communities in redevelopment efforts.

The next two articles describe university efforts to develop and build spaces in downtown areas to expand access to the university, enhance economic vitality of the region, and create opportunities for partnerships. Barthell, Simmons, and Youngblood describe the University of Central Oklahoma (UCO) experiences in developing UCO Downtown. Similarly, Davson, Englot, Fischzang, Fleming, and Kline describe how they created a new space in the city of Newark- “Express Newark”- that benefits Rutgers faculty and students and city inhabitants. 
Three articles describe academic-community partnerships focused on improving educational outcomes. Provinzano, Riley, Levine, and Grant describe Drexel's School of Education partnership with Communities in Schools. Larrivee, Challupka, Cleary, and Comeau describe how Worcester State University engaged with their community to develop a program that improves educational pathways for direct care workers. A group of faculty at California State University San Marcos (CSUSM) — Nuñez-Alvarez, Clark-Ibañez, Ardón, Ramos, and Pellicia— describe their work on increasing the community engagement of their surrounding Latino community though "a culturally and linguistically relevant civics curriculum" delivered to students and their families.

Finally, Golich, Haynes, Hillhouse, and Pfeifer describe how Metropolitan State University of Denver faculty and administrators engaged in iterative conversations with industry leaders to develop a curriculum and designing educational facilities to meet the integrated needs of the university and the region.

\section{References}

AAC\&U (American Association of Colleges and Universities. (n.d.). "High-Impact Practices.” Retrieved from https://www.aacu.org/resources/high-impact-practices.

Boyer, E. (1997). Scholarship Reconsidered: Priorities of the Professoriate. San Francisco, CA: Jossey-Bass.

Coalition for Community Schools. (n.d.). Retrieved from www.communityschools.org/.

CUMU. (2017). "Past Conferences: The Urban Advantage.” Retrieved from

www.cumuonline.org/what-we-do/annual-conference/past-conferences/.

Democracy Collaborative. (2018). "The Democracy Collaborative and the Coalition of Urban and Metropolitan Universities (CUMU) Launch the Higher Education Anchor Mission Initiative in Partnership with 31 Colleges and Universities.” Retrieved from

https://democracycollaborative.org/content/democracy-collaborative-and-cumu-launch-highereducation-anchor-mission-initiative. 